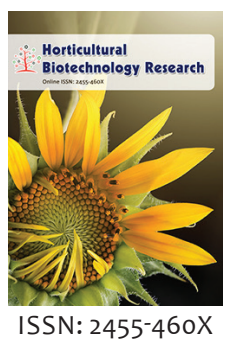

Received: January 11, 2019 Accepted: February 19, 2019 Published: February 27, 2019

*Corresponding Author: Maysoun M. Saleh Email:mzainsamasaleh@ gmail.com

\section{Selection criteria for yield in eggplant (Solanum melongena L.)}

\author{
Maysoun M. Saleh ${ }^{1 *}$, Ossama Muhra1, Zaeda Alsayd Suliman² \\ ${ }^{1}$ General Commission for Scientific Agricultural Research (GCSAR), Genetic Resources Department, Damascus, \\ Syria, ${ }^{2}$ General Commission for Scientific Agricultural Research (GCSAR), Scientific Agricultural Research Center of \\ Homs, Syria
}

\section{INTRODUCTION}

Eggplant (Solanum melongena L.) belongs to Solanaceae family [1] which is cultivated widely in tropic and subtropics regions of the world [2]. It is valuable for human health as it is rich in fiber and vitamins $(\mathrm{C}, \mathrm{B} 6, \mathrm{~K})$ and also minerals like calcium, iron, potassium, and phosphorus [3] and phenolic compounds and anthocyanins with antioxidant properties [4]. Eggplant has low fat content [5], thus making it important to prevent heart diseases and control blood pressure $[6,7]$. In Syria Eggplant is planted in spring and well consumed in many ways. Syrian researchers are interested in collecting local landraces to broaden the genetic variability of new varieties.

Yield is a complex trait which is affected by other traits, so selection for yield will be more successful when taking in consideration of the correlation and path analysis and considered with path coefficient analysis as important biometrical methods [8]. Correlation usually refers only to the ongoing relation between traits, while path analysis divides this relation into direct and indirect effects of each trait towards yield [9]. Earlier study [10] revealed path coefficient analysis in 35 varieties of brinjal (Solanum melongena L.) and the results revealed that the average fruit weight had positive direct effect on fruit yield. Another report evaluated different genotypes of eggplant collected from different parts of Nigeria and studied relationship of some important agronomic traits and their contributions to yield and they found negative correlation between plant height and days to flowering [11]. There are reports on character association and path analysis in eggplant with negative correlation between days to flowering and fruit yield, and fruit weight wasn't correlated significantly with fruit yield [9]. Apart from these studies, there is report on strong positive association between morphological characters and yield in eggplant [12]. Objectives of the present study were to evaluate the traits relations and define their direct and indirect effects via other traits on eggplant yield.

\section{MATERIAL AND METHODS}

Nineteen genotypes of eggplant (Solanum melongena L.) were collected from different places in Syria and planted in rows at Homs Research Centre middle of Syria northern Damascus belongs to the General Commission of Scientific Agricultural research GCSAR in Syria during spring in season 2016 under rainfed conditions (Table A). The experiment was laid out in a Complete Randomized Block Design (RCBD) with three replications. Spaces between rows was $50 \mathrm{~cm}$ and between plants in the same row was also $50 \mathrm{~cm}$. All recommended cultural practices like irrigation and pesticide control were conducted according to agricultural ministry guides, Following traits were studied from randomly ten selected plants according to earlier established method [13]:

- Days to $50 \%$ flowering: Days from sowing to $50 \%$ of flowers opening.

- Days to flower Setting: Days from sowing to flower setting.

Copyright: (-) The authors. This article is open access and licensed under the terms of the Creative Commons Attribution License (http://creativecommons.org/licenses/by/4.0/) which permits unrestricted, use, distribution and reproduction in any medium, or format for any purpose, even commercially provided the work is properly cited. Attribution - You must give appropriate credit, provide a link to the license, and indicate if changes were made. 
- Days to maturity: Days from sowing to maturity of $50 \%$ of plants.

- Plant Height/cm: Recorded at flowering stage.

- Fruit weight/g: Using electric balance for each genotype in each replication.

- Number of harvested Plants.

- Fruit Yield per genotype/kg.

Correlation between traits was studied using SPSS.15, and Path coefficients analysis according to standard method [14] using Genstat.12.

\section{RESULTS AND DISCUSSION}

\section{Correlation}

Results of correlation showed positive and highly significant correlation between each of: days to flowering with days to flower setting $\left(\mathrm{r}=0.941^{* *}\right)$, days to flowering with days to maturity ( $\left.\mathrm{r}=0.694^{*}\right)$, days to flower setting with days to maturity $\left(\mathrm{r}=0.758^{* *}\right)$, plant height with fruit yield $\left(r=0.663^{* *}\right)$, number of harvested plants with fruit yield $\left(r=0.581^{* *}\right)$, while correlation was negative and highly significant between each of: days to flowering with fruit yield $\left(\mathrm{r}=-0.448^{*}\right)$, days to flower setting with fruit yield $(r=-0.490 *)$, and days to maturity with fruit yield $\left(\mathrm{r}=-0.650^{* *}\right)$, days to maturity with plant height $\left(\mathrm{r}=-0.499^{* *}\right)$, the correlation was negative and significant $(\mathrm{r}=-0.302 *)$ between days to flower setting and plant height, while positive significantly between plant height and number of harvested plants $\left(\mathrm{r}=0.267^{* *}\right)$ (Table 2).

Our results are in accordance with earlier report [9] who found negative correlation between days to flowering and fruit yield,

Table (A): Average temperature in spring and summer 2016

\begin{tabular}{lcc}
\hline & Min temperature & Max temperature \\
\hline April & 13 & 25 \\
May & 16 & 27 \\
June & - & - \\
July & 22.19 & 33.4 \\
August & 20.3 & 33.73 \\
September & 19.17 & 30.16 \\
October & 15.90 & 28.58 \\
November & 6.73 & 20.28 \\
\hline
\end{tabular}

Table 1: Genotype collected sites

\begin{tabular}{llcl}
\hline Genotype & Province & Genotype & Province \\
\hline 11326 & Homs & 11971 & Al-Raqqa \\
11787 & Al-Hassake & 11974 & Al-Raqqa \\
11850 & Homs & 12010 & Hama \\
11866 & Homs & 12011 & Hama \\
11901 & Damascus & 12057 & Dair-Ezzor \\
11939 & Al-Raqqa & 12073 & Dair-Ezzor \\
11946 & Al-Raqqa & 12081 & Dair-Ezzor \\
12088 & Dair-Ezzor & 12135 & Aleppo \\
12117 & Aleppo & 12634 & Aleppo \\
12123 & Aleppo & & \\
\hline
\end{tabular}

and correlation wasn't significant between fruit weight and fruit yield, and agree with other reports $[8,11,12]$.

\section{Path Analysis}

Results of path analysis refereed to negative low direct effect of days to maturity on fruit yield $(-0.188883)$, and negative neglected direct effect of days to flowering and days to flower setting $(-0.07528,-0.05396)$ for each of them respectively on fruit yield, while the direct effect of fruit weight on fruit yield was positive and low $(0.13273)$ and was positive and high for number of harvested plants and plant height on fruit yield $(0.35990,0.43954)$ for each of them respectively. Results also showed that days to flowering had negative low indirect effect via days to maturity and plant height $(-0.13099,-0.10685)$ for each of them respectively on fruit yield, as the same as days to flower setting had negative low indirect effect via days to maturity and plant height on fruit yield (-0.14319, -0.13253) for each of them respectively, also days to maturity had negative but medium indirect effect via plant height on fruit yield $(-0.21925)$, the indirect effect of number of harvested plants on fruit yield via plant height was positive and low (0.11740), all other indirect effects were neglected positive or negative on fruit yield (Table 3). These results are in agreement with the results $[8-10,12]$.

\section{CONCLUSION}

It was concluded from results both plant height and number of harvested plants had positive significant correlation with yield, and the direct effect of plant height on yield was the highest followed by the direct effect of number of harvested plants, then the direct effect of fruit weight.

Table 2: Correlation between studied traits

\begin{tabular}{lccccccr}
\hline & FD & FSD & MD & PH & FW & HPN & YI \\
\hline FD & 1 & & & & & & \\
FSD & $0.941^{* *}$ & 1 & & & & & \\
MD & $0.694 * *$ & $0.758 * *$ & 1 & & & & \\
PH & -0.243 & $-0.302^{*}$ & $-0.499 * *$ & 1 & & & \\
FW & -0.066 & -0.127 & -0.126 & -0.011 & 1 & & \\
HPN & -0.209 & -0.202 & $-0.366 * *$ & $0.267 *$ & 0.059 & 1 & \\
FY & $-0.448 * *$ & $-0.490^{*}$ & $-0.650 * *$ & $0.663 * *$ & 0.185 & $0.581 * *$ & 1 \\
\hline
\end{tabular}

Where: * significant at $0.05, * *$ significant at $0.01, \mathrm{FD}$ days to flowering, FSD days to flower setting, MD days to maturity, PH plant height, FW fruit weight, HPN number of harvested plantss, FY fruit yield per genotype.

Table 3: Direct and indirect effect of studied traits on yield

\begin{tabular}{lcccccc}
\hline & MD & PH & FD & FSD & FW & HPN \\
\hline MD & -0.18883 & -0.21925 & -0.05222 & -0.04091 & -0.01671 & -0.13176 \\
PH & 0.09419 & 0.43954 & 0.01830 & 0.01627 & -0.00147 & 0.09612 \\
FD & -0.13099 & -0.10685 & -0.07528 & -0.05077 & -0.00871 & -0.07523 \\
FSD & -0.14319 & -0.13253 & -0.07083 & -0.05396 & -0.01691 & -0.07277 \\
FW & 0.02378 & -0.00487 & 0.00494 & 0.00688 & 0.13273 & 0.02137 \\
HPN & 0.06913 & 0.11740 & 0.01574 & 0.01091 & 0.00788 & 0.35990 \\
\hline
\end{tabular}

Residual effect $=0.2921$. FD days to flowering, FSD days to flower setting, MD days to maturity, PH plant height, FW fruit weight, HPN number of harvested plants. 


\section{RECOMMENDATION}

To depend on plant height and number of harvested plants and fruit weigh as selection criteria to increase final yield of egg plant.

\section{AUTHOR CONTRIBUTIONS}

All authors had an equal contributions.

\section{REFERENCES}

1. Daunay MC, Lester RN, Gebhardt RN, Hennart CH, Jahn JW, Frary MA, Doganlar S. Genetic resources of eggplant (Solanum melongena L.) and allied species: A new challenge for molecular geneticists and eggplant breeders. Solanaceae V. Nijmegen University Press, Nijmegen, Netherlands. 2001;251-274.

2. Manoko, MLK, Van der Weerden GM. Solanum americanum In: G. J. H. Grubben and O. A. Denton (eds.), Plant Resources of Tropical Africa 2. Vegetables. PROTA Foundation Wageningen/ CTA Wageningen, Backhuys Publishers, Leiden, the Netherlands. 2004; 477-480p.

3. Bhatti KH, Kausar N, Rashid U, Hussain K, Nawaz K, Siddiqi EH. Effects of biotic stresses on eggplant (Solanum melongena L.). World Applied Sciences Journal. 2013;26(3): 302-311.

4. Aramendiz-Tatis H, Espitia M, Cardona C. Análisis de sendero en berenjena (Solanum melongena L.). UDCA Actual. Divulg. Cient. 2010;13:115-123.

5. Robinson JP, Saranya S. An improved method for the In Vitro propagation of Solanum melongena L. International Journal of Current Microbiology and Applied Sciences. 2013;2(6): 299-306.

6. Grubben, GJH, Denton OA. Plant Resources of Tropical Africa II: Vegetables, Leiden, Wageningen: Backhuys Publishers, 2004.

7. Okon UE, Enete AA, Oluoch MO. Characterization of African eggplant for morphological characteristics. Journal of Agriculture Science and Technology. 2010;(3):3337.

8. Ram Ashish Gupta, Ram CN, Satish Kr. Chakravati, Chandra Deo, Vishwakarma MK, Gautam DK, Pushpendra Kumar. Studies on correlation and path coefficient analyses in brinjal (Solanum melongena L.). International Journal of Current Microbiology and Applied Sciences. 2017;6(7):4543-4548.

9. Tripathy B, Sharma D, Singh J, Nair SK. Correlation and path analysis studies of yield and yield components in brinjal (Solanum melongena L.). International Journal of Pure and Applied Bioscience. 2018;6(1):1266-1270

10. Ravali B, Saidaiah P, Ravinder Reddy K, Shivraj N, Geetha A. 2017 Study on character association and path analysis in brinjal (Solanum melongena L.). Journal of Pharmacognosy and Phytochemistry. 2017;6(6): 393-397.

11. Akpan NM, Ogbonna PE, Onyia VN, Ockechukwu EC, Atugwu IA Variability studies on ten genotypes of eggplant for growth and yield performance in south eastern Nigeria. The Journal of Animal and Plant Sciences. 2016;26(4):1034-1041.

12. Chauhan A, Chandel KS, Singh SP. Studies on correlation and path analysis for yield and yield contributing traits in eggplant (Solanum Melongena L.) involving bacterial wilt resistant genotypes. Vegetos. 2017;30:4

13. IBPGR. 1990. Descriptors for Eggpalnt. International Board for Plant Resources, Rome, Italy.

14. Singh BK, Chudhary BD. Biometrical methods in quantitative genetic analysis. Kalyani Publishers. New Delhi, 1977. 